\title{
Whether the Construction of the Free Trade Zone Will Help Improve the Total Factor Productivity of Enterprises-Evidence from Chinese A-Share Listed Companies
}

\author{
Chao Zhou ${ }^{1}$ \\ ${ }^{1}$ School of Central University of Finance and Economics, Beijing, China \\ Correspondence: Chao Zhou, School of Central University of Finance and Economics, Beijing, China.
}

Received: January 3, 2020

Accepted: January 24, 2020

Online Published: February 10, 2020

doi:10.5539/ibr.v13n3p15

URL: https://doi.org/10.5539/ibr.v13n3p15

\begin{abstract}
Since the establishment of the first free trade zone in Shanghai in 2013, as of 2018, China has successively established 13 free trade zones. This paper uses a multi-period difference method and uses the financial data of Chinese A-share listed companies to prove the construction of the FTZ help to improve the TFP of the enterprise. The annual patent data obtained by the company is used to empirically analyze the role of innovation as a mediating effect in the development of the FTZ. In the end, it is believed that the construction of the FTZ can improve the TFP of enterprises through intermediary effects and regulatory effects.
\end{abstract}

Keywords: FTZ, TFP, multi-period difference, innovation-driven, heterogeneity

\section{Introduction}

The subprime crisis broke out in the United States in 2008, which led to the global financial crisis. This crisis has led to sluggish global economic growth, and the world economy has been undergoing in-depth adjustments. Some countries and regions have begun to implement trade protectionism for the development of their own economies, the idea of inverse globalization is gradually rising. In order to dealing with this situation, the Chinese government has begun to transform China's economic development mode, and believe that the Chinese economy should change from relying on export and foreign trade to open economic development. Free trade zones came into being in this context. In August 2013, Shanghai Free Trade Zone was formally established with the approval of the State Council; in April 2015, Guangdong, Tianjin, and Fujian free trade zones were established; in August 2016, with the approval of the government, Liaoning, Zhejiang, Henan, Hubei, and Chongqing were established 7 free trade zones including Sichuan, Shaanxi, and Shaanxi, and were officially listed in March 2017. China's free trade zone has formed a pattern of $1+3+7$. The free trade zone has become an entry point for China's reforms in the fields of trade, investment and finance to promote China's supply-side structural reforms and improve the quality of national economic development. Economic effects have become a focus of academic research.

The academic community has two opposing views on the establishment of a free trade zone, which can be divided into positive and negative views. The positive view is that the FTZ can eliminate some international trade barriers, use global advanced resources, and reduce transactions at the same time. Cost can promote global economic development. The main representatives are Krugman (1993), Venables (2003), Chauffour and Maur (2011), Feils and Rahman (2008). These views believe that the FTZ can promote economic development among member states. To increase social welfare and increase the total factor productivity of enterprises. The negative view is that the free trade zone will increase the imbalance in regional economic development, hinder the flow of resources and trade within and outside the trade zone, and also increase the Wage gaps and even distorting trade costs. The main representatives are Polaski (2006), Jenkins and Kuo (2013), and Siroën and Yücer (2014). It can be seen that the academic community on the economic effects of the free trade zone exists Big differences.

\section{Literature Review}

(I) Economic effects of the free trade zone

Most of the domestic researches on the free trade zone are conducted from a qualitative perspective. The Expert Group of Shanghai University of International Business and Economics (2013) discussed in detail the 
development background and various policies of the Shanghai Free Trade Zone, which provided many references for the free trade zone research. Shuanghua Chen, Lingyun Tao and Jing Huang (2014) compared Shanghai and foreign free trade zones from the perspective of service trade development, and proposed policy recommendations on how China's service trade should develop. Aizhen Chen and Zhibiao Liu (2014) believe that establishment of the Shanghai Free Trade zone can optimize the allocation of resources and promote economic growth. Yujiang Bi, Haiyan Tang and Desheng Yin (2014) proposed how to promote the development of China's service trade through trade transformation based on the trade zone. Qi Chen and Wei Liu (2014) believe that The establishment of the Shanghai Free Trade Zone has both positive and negative effects. On the one hand, the free trade zone can promote the efficient allocation of resources, bring about industrial agglomeration and economies of scale, and enjoy institutional dividends; on the other hand, the free trade zone may attract other regions' Resources, which have a crowding-out effect on other regions, are not conducive to coordinated and balanced economic development, or even to overall economic growth. Xiangdong Yang (2014) believes that the "pre-admission national treatment" and "negative list" models of the free trade zone can promote economic development in the free trade zone by reducing taxes and transaction costs, and more fair competition among enterprises. Bin Sheng (2017) believed the establishment of the free trade zone evaluated the results from several different perspectives and made policy recommendations on how to better develop the free trade zone.

In recent years, with the increase in the number of years of implementation of the free trade zone, some scholars have begun to study the economic effects of the free trade zone from a quantitative perspective. Na Tan et al. (2015) used a counterfactual analysis method to believe that the establishment of the Shanghai Free Trade Zone has improved Shanghai the industrial added value and the total value of imports and exports increased by 2.69 and 6.73 percentage points year-on-year, respectively. Houjun Xiang and Kang He (2016) applied the method of psm-did and synthetic control to believe that the establishment of the Shanghai Free Trade Zone has a significant impact on capital flows. After the establishment of the free trade zone, the changes in foreign investment are far greater than the actual use of foreign capital. Lihui Wang and Zhihong Liu (2017) used panel data policy effect assessment methods and synthetic control methods to analyze economic indicators at the macro and micro levels, and concluded that the free trade zone has a positive economic impact on economic growth. Binglian Liu and Cheng lv (2018) analyzed the economic effects of four free trade zones in Shanghai, Tianjin, Guangdong, and Fujian using synthetic control methods. Both growth and investment in fixed assets can have significant positive impacts to varying degrees, and there are obvious differences in the economic effects of different free trade zones. Binglian Liu and Yan Wang (2018)Using the synthetic control method to construct a "counterfactual" sample, it is believed that the establishment of the Shanghai Free Trade Zone can significantly promote the improvement of Shanghai's innovation level.

\section{(II) Measurement of Total Factor Productivity (TFP)}

Total factor productivity is usually called the rate of technological progress, and is mainly used to measure the increase in productivity caused by factors other than tangible factors of production. The measurement of total factor productivity is mainly parametric and non-parametric method. The non-parametric method is mainly based on the index method, DEA method, and Malmquist index method are mainly used. The parametric methods mainly include the Solow residual method, the invisible variable method, and the stochastic frontier method. Whether it is a parametric method or a non-parametric method, it has its own limitations. The method of measuring total factor productivity is based on the availability and availability of the data used to analyze the problem.

Massimo (2008) proposed methods to divide the TFP dimension, and through these methods, the level value and growth rate of TFP can be measured. Xiaodong Lu and Yujun Lian (2012) summarized the methods for measuring the total factor productivity of enterprises. It is believed that there are more methods for measuring TFP at the macro level, while there is less literature for measuring TFP at the micro-enterprise level, and specific methods and corresponding stata commands for measuring TFP are given. Qianli Xie (2008) used the parametric method The total factor productivity of Chinese industrial enterprises was measured. Jie Zhang (2009) used the non-parametric OP method to estimate the total factor productivity of Chinese state-owned enterprises and large non-state enterprises from 1999 to 2003. However, the OP method is used to estimate the total factor productivity. There is a rigid requirement that the monotonic relationship between investment and output must be maintained, which means that it is not possible to calculate the total factor productivity of a company with zero investment. Levinsonhn and Petrin (2003) developed a new half of the defect of the OP method. The parametric method is used to measure the total factor productivity of an enterprise. The investment amount is no longer used as a proxy variable, but the intermediate input is used as a proxy variable. The contribution is to enable researchers to 
flexibly choose variables based on the data obtained to calculate corporate TFP.

In view of the above reviews, the economic effects of studying the free trade zone are mostly analyzed using macro data at the provincial level, and are mainly based on the analysis of the Shanghai Free Trade Zone. The quantitative analysis methods are mostly synthetic control methods or psm-did methods. No related articles were analyzed from the micro data to analyze China's free trade zone. One of the shortcomings of using macro data is that it is difficult to solve the endogenous problem. In the analysis, Shanghai and Tianjin are relatively reasonable as urban analysis. The trade zone has only selected some parts of the province, and the analysis of the province's data has certain limitations. This article uses the data of a-share listed companies to analyze the impact of the free trade zone on total factor productivity, which can be more A detailed analysis can avoid the limitation of using provincial data in free trade zones such as Guangzhou and Fujian. Because of the time difference in the implementation of policies in the free trade zone, it is difficult to study the causality of the policy in the following areas. (1) There is a mutual cause and effect problem in the construction of the free trade zone and the improvement of total factor productivity. The construction of the free trade zone can improve the increase of total factor productivity. It is officially because of the convenience of trade in the place where the free trade zone is established. Before it became a free trade zone.(2) There are certain selective errors. The construction of the free trade zone was established after comprehensive evaluation by the State Council and local governments. These regions have their own unique characteristics, and it is difficult to choose a suitable control group.(3) Because the construction of different free trade zones is not at the same point in time, the traditional double difference will no longer apply to the identification of total factor productivity improvement in the free trade zone.

The writing of this paper will mainly focus on the following points: (1) Constructing a theoretical mechanism for the improvement of total factor productivity in the free trade zone and proposing corresponding research hypotheses; (2) This paper is based on the data of Chinese listed companies from 2004 to 2018, the multi-period difference method is used to evaluate whether the construction of the free trade zone promotes the increase of total factor productivity; (3) This article tests the effectiveness and robustness of the effectiveness of the free trade zone policy; (4) Using the mediation effect model validate the theoretical mechanism of FTZ construction affecting TFP; (5)Finally, Giving forward conclusions and policy recommendations on the impact of FTZ construction on TFP.

\section{Theoretical Mechanism and Research Hypothesis}

The purpose of the construction of the free trade zone is to respond to the new normal of economic growth and promote supply-side structural reforms by further opening up to the outside world. This major measure of free trade zone construction can be piloted to study whether the free trade zone can actually promote local economic development. Realize the simultaneous improvement of economic growth rate and the quality of economic growth. Enterprises in the free trade zone can enjoy tax benefits, foreign companies can enjoy national treatment, and realize the free flow of capital and fair competition of enterprises. The impact is mainly achieved through the following two effects: (1) Innovation-driven effects. According to the Cobb-Douglas production function and the Solow model, in addition to labor and capital, technological progress can promote increased output and play a very important role. Technology Innovation can bring higher production efficiency to the enterprise, thereby promoting the improvement of the company's total factor productivity.(2) The effect of resource allocation, more reasonable resource allocation will inevitably require enterprises to have stronger management capabilities and clear invisible barriers, which will improve the total factor productivity of enterprises. The construction of the free trade zone has eliminated trade barriers and allowed the market to a greater role will be played in resource allocation, and a more important role in the market will lead to a higher resource allocation efficiency, which will promote the increase in the total factor productivity of enterprises in the free trade zone.

\section{(I) Construction of FTZ promotes improvement of TFP through innovation-driven effects}

According to the theory of endogenous growth, knowledge and technology play an important role in promoting economic growth, and innovation can promote economic growth. The establishment of the free trade zone has enabled enterprises to face more free markets and fairer competition, and has also paid more attention to corporate innovation and Intellectual property rights protection. Free trade zone promotes the improvement of total factor productivity through innovation. (1) The construction of the free trade zone is an institutional innovation. Youwen Zhang (2014) believes that the construction of the free trade zone can accelerate the innovation of the financial system. Help financing of high-tech enterprises.(2) The high opening of the free trade zone enables companies to face a more free market environment and lower transaction costs when acquiring FDI and investing in ODI. Of course, to survive in such a highly open and competitive market environment, 
companies must constantly carry out technological innovation to improve its own competitiveness.(3) The policies of the free trade zone will also attract high-quality talents. Bingxian Liu and Yan Wang (2018) believe that the free trade zone can make the region's knowledge and technology collide more frequently, and the knowledge spillover effect produced will promote innovation and progress. In summary, the construction of the free trade zone can promote the improvement of the level of innovation, and the effect of the level of innovation on enterprises will increase the total factor productivity of the enterprise. Based on the above analysis, this article proposes the following research hypothesis. The level of innovation in the construction and productivity of the free trade zone plays an intermediary role, and the construction of the free trade zone can have a positive impact on total factor productivity through innovation-driven effects.

(II) The construction of FTZ improves the TFP of enterprises through the effect of resource allocation

The purpose of the construction of the free trade zone is to reduce trade barriers and exclude some enterprises that are not conducive to the development of the free trade zone through a negative list. This can not only better play the role of the market in the allocation of resources, but also use government intervention to exclude areas that significantly affect regional development. The free trade zone can improve total factor productivity through resource allocation mainly through the following channels. (1) Yibing Ding et al. (2014) believe that the free trade zone can optimize the allocation of funds and reduce the company's financing costs and financing difficulties, easing corporate financing constraints, enhancing corporate R\&D investment and innovation capabilities, are conducive to improving total factor productivity.(2) Qingyong Liu et al. (2017) believe that the construction of the free trade zone can alleviate the problem of information asymmetry in enterprises, and promote the communication and exchange of information between enterprises. Optimized allocation of information resources can improve the total factor productivity of enterprises.(3) Chengfeng Zhuo et al. (2018) believe that the construction of the free trade zone can promote the flow of production factors, reduce the cost of acquiring advanced technology, improve the overall management level of the enterprise, and promote the improvement of the company's total factor productivity. Based on the above analysis, this paper proposes the following hypothesis. The enterprises in the free trade zone have a higher ability to allocate resources the construction of the free trade zone can improve the total factor productivity of enterprises through the adjustment effect of resource allocation.

\section{Research Methods and Data Description}

This paper uses a multi-period difference method to evaluate the free trade zone construction to promote total factor productivity improvement, and then further tests and discusses the robustness of the results and its transmission mechanism.

\section{(I) Model Construction}

This paper refers to Thorsten Beck 's et al. (2010) thoughts on multi-phase difference, and conducts an empirical investigation on whether the construction of the free trade zone promotes the improvement of total factor productivity. This paper only looks at 11 free trade zones including Shanghai, Tianjin, Guangdong, Fujian, Liaoning, Zhejiang, Henan, Hubei, Chongqing, Sichuan and Shaanxi. The enterprises in the provinces and cities where the free trade zone is located are set as experimental groups, and the enterprises in other provinces and cities are used as the control group. The time of the establishment of the free trade zone is used as a dividing point. The sample from 2004 to 2018 is divided into four parts. The establishment of the free trade zone enterprises in provinces and cities, enterprises in provinces and cities without a free trade zone, enterprises in provinces and cities before the establishment of a free trade zone, and enterprises in provinces and cities after the establishment of a free trade zone. Time is used as a time dummy variable for the establishment of a free trade zone, Group As dummy variables for establishing a free trade zone, these two sets of dummy variables are represented by 0 and 1 . The specific measurement model is constructed as follows

$$
T F P_{\text {it }}=\alpha_{0}+\alpha_{1} \text { Time } \times G \operatorname{roup}+\sum_{\mathrm{i}=1}^{N} \beta X_{\mathrm{it}}+\mu_{\mathrm{it}}+v_{\mathrm{it}}+\varepsilon_{\mathrm{it}}
$$

In the above formula, $\mathrm{i}$ represents the province, $\mathrm{t}$ represents the year, TFP is used as an explanatory variable, which represents the total factor productivity of each enterprise, and $\mathrm{X}$ represents a set of control variables, including the age of the enterprise, the nature of the owner of the business, the net profit margin on sales, the net profit margin on total assets, Variables such as asset-liability ratio and current ratio. Time is used as a time dummy variable. The value is set to 1 after the establishment of the free trade zone, and 0 before the establishment of the free trade zone. Group as a dummy variable for whether the company is in the free trade 
zone, and the value is 1 in the free trade zoneland 0 not in the free trade zone.Time $\times$ Group As a double difference term, The coefficient $\alpha_{1}$ is the most concerned variable, and this coefficient reflects the impact of free trade zone policies on total factor productivity.

\section{( II ) Parallel trend test}

To examine the policies of the free trade zone using the double difference method, it is necessary to meet the parallel trend. If the time point of the free trade zone is a single time point, such as all free trade zones were implemented in 2013, you can use the graph to observe whether the experimental group and the control group meet the parallel trend before the establishment of the free trade zone. However, the establishment time of different free trade zones is not at the same time. At this time, the parallel trend test is performed. Refer to Thorsten Beck et al. (2010), using the counterfactual method, Advance the time of all free trade zones at the same time or delay it at the same time to see whether the free trade zone policies have significantly improved the total factor productivity. If counter-factual methods are used, the early implementation of free trade zone policies will not have a significant impact on total factor productivity, but the implementation will be delayed. All policies have a significant impact on total factor productivity, and it is considered that the FTA policy was in line with parallel trends before its implementation. The equation for the parallel trend test of this method is as follows:

$$
T F P_{\mathrm{it}}=\beta_{0}+\beta_{1} \mathrm{D}_{i t}^{-10}+\beta_{2} \mathrm{D}_{i t}^{-9}+\ldots .+\beta_{15} \mathrm{D}_{i t}^{+5}+\sum_{\mathrm{i}=1}^{N} \eta X_{\mathrm{it}}+\mu_{\mathrm{it}}+v_{\mathrm{it}}+\varepsilon_{\mathrm{it}}
$$

Among them, $T F P_{i t}$ Represents the total factor productivity of enterprise $\mathrm{i}$ in the t-year, D represents the dummy variable of time, and the number of periods in which the policy is advanced or lagging. The reason why the 10 periods ahead and 5 periods are chosen is because the data used is 2004-2018, and the earliest established The Shanghai Free Trade Zone is 2013, with 9 periods forward and 5 periods backward. However, as of 2018, there are still many provinces that have not implemented the free trade zone policy. In order to measure the number of years to implement the free trade zone, All enterprises that have not implemented the free trade zone policy are placed in the 10 period in advance.

Figure 1 is a multi-period did parallel trend test, using a 95\% confidence interval, and observing the estimated coefficients taking into account the lag of the control variable. $\beta$ Trend of changes, according to the results we found $\beta$ The coefficient did not pass the significance level test in 2004-2015, and passed the significance level test in 2016-2018. It shows that since the establishment of the Shanghai Free Trade Zone in 2013, the policy has shown obvious effects from 2015, which also shows that the experiment The group and control group met the parallel trend hypothesis before implementing the policy.

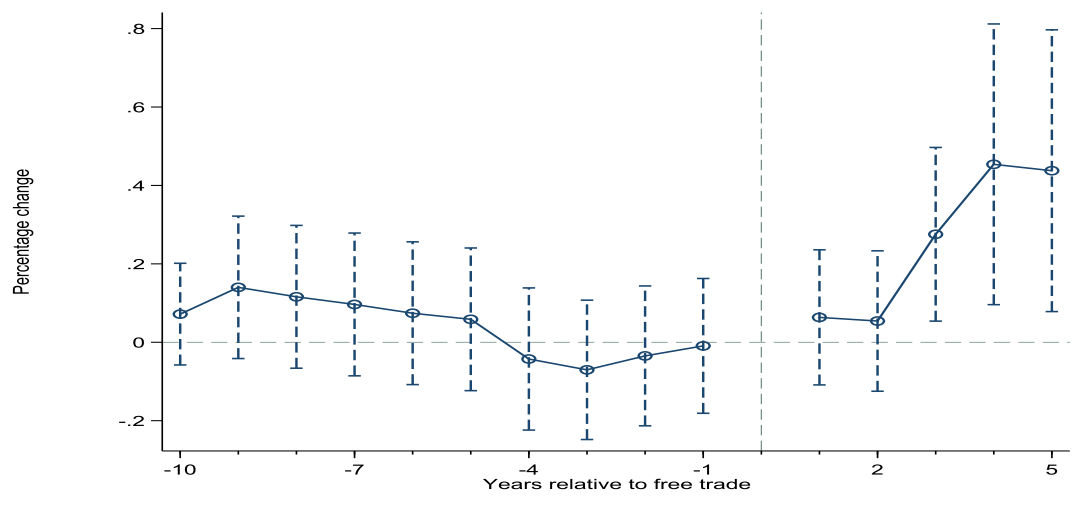

Figure 1. Parallel Trend Test

\section{(III) Selection of indicators}

Explained variable is TFP, which reflects the increase in output driven by factors other than capital, labor, and

\footnotetext{
${ }^{1}$ To determine whether an enterprise is in a free trade zone or not, based on whether the enterprise is in a province or city, if the company is located in a province or city where 11 free trade zones are located, the Group value is 1 .
} 
intermediate inputs. About how to measure total factor productivity, as described in the second part of this paper. The most commonly used method to measure the total factor productivity of an enterprise is the OP method and the LP method. Because the OP method requires that the enterprise's real investment must be greater than 0 , this limitation will lose many corporate samples. Therefore, this article uses the LP method to measure total factor productivity. Using enterprise value-added to estimate TFP is a better solution. There are two methods to measure value-added: production method and distribution method. Whether the production method or the income method is based on financial data, it can't calculate more accurate value-added. Benwei Hu (2014) uses enterprise operating costs, three major expenses, and advanced measurement of current inputs for depreciation of fixed assets and amortization of intangible assets, payments to employees, and payments for employees. Total output is measured using operating income, but this article uses this method to measure, it was found that many added values were calculated as negative numbers, and Liya Liu et al. (2018) used depreciation, labor compensation, net production tax and operating profit to measure the added value, it is difficult to accurately measure the net production tax and operating surplus when the method is difficult. Therefore, this paper uses Xiaodong Lu and Yujun Lian (2012) to use the LP method to measure total factor productivity and use operating income, represents the total output, the number of employees in the enterprise to measure the labor factors, the net fixed asset value to measure the capital input, the expenditure on purchasing goods and services to measure the intermediate input, and the above indicators are used to measure the total factor productivity according to the LP method.

\section{Data Source}

The data in this article are mainly from Wind and CSMAR databases, as well as the National Bureau of Statistics and China Economic Network. In order to avoid the problem of selective bias, this paper selects the corporate financial data of A-share listed companies from 2004 to 2018, and according to the CSRC and Wind the industry classification method of the company classifies companies by industry. These listed companies are generally large in scale, and their financial data are audited data, which is relatively more accurate. In selecting the data, this article aims to obtain balanced panel data. Benchmark, excluding T companies that have serious lack of financial data and subsequently become S. After finishing, there are 506 companies each year, 235 companies located in the free trade zone, 271 companies outside the free trade zone, 15 years of data. There are 7590 samples in total. In order to improve the comparability of the data, this article collected the industrial producer price index and fixed asset investment price index from the China Economic Net, referring to the processing method of most articles, using the industrial producer price index for business income data. Deflation, other financial data were deflated using the fixed asset investment price index, and both indicators chose 2000 as the base period, as shown in Table 1.This paper main variables descriptive statistics.

Table 1. Variable descriptive statistics

\begin{tabular}{|c|c|c|c|c|c|}
\hline variable & Mean & Standard deviation & Minimum value & $\operatorname{Max}$ & Observations \\
\hline TFP & 9.922 & 1.026 & 4.581 & 13.923 & 7590 \\
\hline $\begin{array}{l}\text { Logarithm of } \\
\text { operating } \\
\text { income }\end{array}$ & 16.797 & 1.554 & 10.145 & 22.669 & 7590 \\
\hline $\begin{array}{l}\text { Log of net } \\
\text { fixed assets }\end{array}$ & 15.839 & 1.627 & 7.406 & 21.379 & 7590 \\
\hline $\begin{array}{l}\text { Logarithm of } \\
\text { goods and } \\
\text { services } \\
\text { purchased }\end{array}$ & 16.318 & 1.612 & 8.052 & 22.478 & 7590 \\
\hline $\begin{array}{l}\text { Logarithm of } \\
\text { labor force }\end{array}$ & 8.012 & 1.236 & 2.303 & 12.290 & 7590 \\
\hline Sales margin & 0.045 & 0.793 & -20.897 & 35.931 & 7590 \\
\hline $\begin{array}{l}\text { Total net asset } \\
\text { interest rate }\end{array}$ & 0.031 & 0.144 & -1.681 & 10.032 & 7590 \\
\hline $\begin{array}{c}\text { Assets and } \\
\text { liabilities }\end{array}$ & 0.541 & 0.419 & 0.007 & 13.711 & 7590 \\
\hline Current ratio & 1.565 & 2.942 & 0.036 & 204.72 & 7590 \\
\hline
\end{tabular}

Data source: collated according to wind data

\section{Analysis of the Effect of the Construction of FTZ on TFP}

As a major national decision, the free trade zone is intended to further open up the Chinese economy and Chinese companies can make better use of international advanced technology, management experience and funds, and make it easier for them to make overseas investments. The level and the efficiency of resource allocation 
promote the improvement of total factor productivity. The construction of the free trade zone can be used as a quasi-natural experiment to evaluate the impact of the construction of the free trade zone on total factor productivity using a gradual double difference method.

(I) Benchmark regression of the construction of free trade zone to total factor productivity

Table 2 reports the multi-period did benchmark regression model. The total factor productivity measured by the lp method is used as the explanatory variable, and whether the free trade zone was established at a specific time as the core explanatory variable. Model 1 and Model 2 do not control time and industry. Benchmark regression model of effects; Models 3 and 4 are benchmark regression models that control time and industry effects. Comparing (2) and (4) in Table 2 we can see that time and industry have a great impact on total factor productivity, Controlling the industry and time, the free trade zone 's interpretation factor for total factor productivity has become smaller. This should be consistent with our economic intuition. From 2004 to 2018, whether the company is in the free trade zone or not, the production technology of the surviving enterprises And management level will inevitably have great development. This article focuses on the effect of the free trade zone policy. After controlling time and industry factors, the free trade zone policy still has a significant positive impact on total factor productivity, proving that the free trade zone policy can promote Development of total factor productivity.

Table 2. Benchmark regression models

\begin{tabular}{|c|c|c|c|c|}
\hline & (1) & $(2)$ & (3) & (4) \\
\hline Time $\times$ Group & $\begin{array}{l}0.498^{* * *} \\
(0.023)\end{array}$ & $\begin{array}{l}0.235^{* * *} \\
(0.029)\end{array}$ & $\begin{array}{c}0.032 \\
(0.072)\end{array}$ & $\begin{array}{l}0.077^{* *} \\
(0.032))\end{array}$ \\
\hline Business age & & $\begin{array}{l}0.146^{* * *} \\
(0.001)\end{array}$ & & $\begin{array}{l}-0.005^{* * *} \\
(0.002)\end{array}$ \\
\hline $\begin{array}{c}\text { Whether the enterprise } \\
\text { is a state-owned } \\
\text { enterprise }\end{array}$ & & $\begin{array}{l}0.046^{* * *} \\
(0.019)\end{array}$ & & $\begin{array}{l}0.048^{* * *} \\
(0.018)\end{array}$ \\
\hline $\begin{array}{l}\text { Logarithm of labor } \\
\text { force }\end{array}$ & & $\begin{array}{l}0.463^{* * *} \\
(0.008)\end{array}$ & & $\begin{array}{l}0.441^{* * *} \\
(0.008)\end{array}$ \\
\hline Sales margin & & $\begin{array}{l}0.053^{* * *} \\
(0.011)\end{array}$ & & $\begin{array}{l}0.046^{* * *} \\
(0.011)\end{array}$ \\
\hline Return on Assets & & $\begin{array}{l}0.913^{* * *} \\
(0.062)\end{array}$ & & $\begin{array}{l}0.907^{* * * *} \\
(0.061)\end{array}$ \\
\hline Assets and liabilities & & $\begin{array}{c}0.027 \\
(0.021)\end{array}$ & & $\begin{array}{l}0.053^{* * *} \\
(0.021)\end{array}$ \\
\hline Current ratio & & $\begin{array}{l}0.008^{* * *} \\
(0.003)\end{array}$ & & $\begin{array}{l}0.007^{* * *} \\
(0.024)\end{array}$ \\
\hline Constant term & 9.866 & 5.752 & 9.406 & 5.933 \\
\hline Industry fixed & $\mathrm{N}$ & $\mathrm{N}$ & $\mathrm{Y}$ & $\mathrm{Y}$ \\
\hline Fixed time & $\mathrm{N}$ & $\mathrm{N}$ & $\mathrm{Y}$ & $\mathrm{Y}$ \\
\hline Within $-R^{2}$ & 0.064 & 0.388 & 0.119 & 0.512 \\
\hline
\end{tabular}

Note: The parentheses in the parentheses are firm standard errors at the enterprise level. ${ }^{* * *},{ }^{* *}$, and ${ }^{*}$ are significant at the levels of $1 \%, 5 \%$, and $10 \%$, respectively.

(II) Influencing mechanism of FTZ policy to promote TFP

How does the free trade zone policy affect total factor productivity? According to the theoretical mechanism analysis in Part III, this paper conducts an empirical test on the innovation-driven effect of the construction of the free trade zone.

Innovation is an important factor that promotes the improvement of total factor productivity. This article considers the technological innovation of enterprises as a mediating variable to promote the increase of total factor productivity in the free trade zone. The study of this variable is based on the known free trade zone to promote the growth of total factor productivity. To explore the internal mechanism between the two. This article uses the annual number of patents of listed companies announced by the State Intellectual Property Office as a proxy variable to measure the level of technological innovation of enterprises.

According to Jing Tan and Jianhua Zhang (2018) 's systematic introduction to the intermediary effect, the steps to construct the intermediary effect are: (1) Review the free trade zone on total factor productivity. If the 
coefficient is significantly positive, it means that the construction of the free trade zone can promote Factor productivity; (2) The free trade zone regresses the number of annual patents of the company. If the coefficient is significantly positive, it means that the construction of the free trade zone is conducive to the improvement of the innovation level of the enterprise; (3) The number of patents is used to explain the improvement of the company's total factor productivity. If the coefficient is significantly positive, it means that technological innovation can promote the increase of total factor productivity; (4) Use the free trade zone policy and industrial structure to explain total factor productivity at the same time to see if the coefficient is significant. As mentioned above, construct a mediation effect model:

$$
\mathrm{TFP}_{i t}=\alpha_{0}+\alpha_{1} T \times G+\alpha_{2} a g e_{i t}+\alpha_{3} l n L_{i t}+\alpha_{4} n p m_{i t}+\alpha_{5} \text { roa }_{i t}+\alpha_{6} t d r_{i t}+\alpha_{7} \text { liquidityratio }_{i t}+\varepsilon_{i t}
$$

lnPatent $_{i t}=\beta_{0}+\beta_{1} T \times G+\beta_{2}$ age $_{i t}+\beta_{3} \ln L_{i t}+\beta_{4} n p m_{i t}+\beta_{5}$ roa $_{i t}+\beta_{6} t d r_{i t}+\beta_{7}$ liquidityratio $_{i t}+\gamma_{i t}$

$\mathrm{TFP}_{i t}=\chi_{0}+\chi_{1} \operatorname{lnPatent}_{i t}+\chi_{2} a g e_{i t}+\chi_{3} \ln L_{i t}+\chi_{4} n p m_{i t}+\chi_{5}$ roa $_{i t}+\chi_{6} t_{d r_{i t}}+\chi_{7}$ liquidityratio $_{i t}+\xi_{i t}$

$$
\begin{gathered}
\mathrm{TFP}_{i t}=\delta_{0}+\delta_{1} \operatorname{lnPatent}_{i t}+\delta_{2} \mathrm{~T} \times \mathrm{g}+\delta_{3} a_{g e_{i t}}+\delta_{4} \ln L_{i t}+\delta_{5} n p m_{i t}+\delta_{6} \text { roa }_{i t}+\delta_{7} t d r_{i t} \\
+\delta_{8} \text { liquidityratio }_{i t}+v_{i t}
\end{gathered}
$$

Among them, TFP is the total factor productivity, TXG is the policy variable for the construction of the free trade zone, age is the age of the company, owner is the nature of the business owner, $\operatorname{lnL}$ is the logarithm of the number of employees, npm is the net sales margin, and roa is the return on assets, tdr represents the

\begin{tabular}{|c|c|c|c|c|}
\hline variable & $(1)$ & (2) & (3) & $(4)$ \\
\hline$T \times G$ & $\begin{array}{l}0.211^{\text {**** }} \\
(0.031)\end{array}$ & $\begin{array}{l}0.227^{\text {**** }} \\
(0.080)\end{array}$ & 一 & $\begin{array}{c}0.193^{* * * *} \\
(0.030))\end{array}$ \\
\hline lnPatent & - & - & $\begin{array}{l}0.081^{* * * *} \\
(0.004)\end{array}$ & $\begin{array}{l}0.079^{* * * *} \\
(0.004))\end{array}$ \\
\hline age & $\begin{array}{l}0.016^{* * * *} \\
(0.001)\end{array}$ & $\begin{array}{l}0.054^{* * *} \\
(0.004)\end{array}$ & $\begin{array}{l}0.016^{* * * *} \\
(0.001)\end{array}$ & $\begin{array}{l}0.013^{* * *} \\
(0.001)\end{array}$ \\
\hline $\ln L$ & $\begin{array}{l}0.478^{* * *} \\
(0.008)\end{array}$ & $\begin{array}{l}0.625^{* * *} \\
(0.020)\end{array}$ & $\begin{array}{l}0.429^{* * * *} \\
(0.008)\end{array}$ & $\begin{array}{l}0.429^{* * * *} \\
(0.008)\end{array}$ \\
\hline npm & $\begin{array}{l}0.037^{* * * *} \\
(0.012)\end{array}$ & $\begin{array}{c}0.003 \\
(0.031) \\
\end{array}$ & $\begin{array}{c}0.037^{* * *} \\
(0.012))\end{array}$ & $\begin{array}{l}0.037^{* * * *} \\
(0.012)\end{array}$ \\
\hline roa & $\begin{array}{c}0.933^{* * * *} \\
0.066\end{array}$ & $\begin{array}{c}-0.072 \\
(0.171)) \\
\end{array}$ & $\begin{array}{l}0.936^{* * * *} \\
(0.065)\end{array}$ & $\begin{array}{l}0.939^{* * * *} \\
(0.065))\end{array}$ \\
\hline$t d r$ & $\begin{array}{l}0.052^{* * *} \\
(0.023) \\
\end{array}$ & $\begin{array}{l}-0.127^{* * *} \\
(0.058) \\
\end{array}$ & $\begin{array}{l}0.052^{* * *} \\
(0.022)\end{array}$ & $\begin{array}{l}0.062^{* * * *} \\
(0.022)\end{array}$ \\
\hline liquidityratio & $\begin{array}{l}0.009^{* * * *} \\
(0.003)\end{array}$ & $\begin{array}{c}0.002 \\
(0.008) \\
\end{array}$ & $\begin{array}{l}0.009^{* * * *} \\
(0.003)\end{array}$ & $\begin{array}{l}0.009^{* * * *} \\
(0.003))\end{array}$ \\
\hline Cons & 5.649 & -3.59 & 5.897 & 5.94 \\
\hline Within $-R^{2}$ & 0.386 & 0.158 & 0.409 & 0.412 \\
\hline Observations & 7590 & 7590 & 7590 & 7590 \\
\hline
\end{tabular}
asset-liability ratio, and liquidityratio represents the current ratio.

Table 3. Innovation-driven mediation effects

Note: 1. The parentheses in parentheses are firm standard errors at the enterprise level. ***,**, and $*$ are significant at the levels of $1 \%, 5 \%$, and $10 \%$, respectively.

2. Column (1)-(4) regression represents panel regression on equations (3)-(6), respectively.

\section{Heterogeneity Analysis of TFP in the Construction of Free Trade Zone}

Although this paper has discussed the positive impact of the free trade zone on total factor productivity, will the pilot scope be for companies of different natures, and will there be certain differences in different regions? Discussing this issue can help to understand the mechanism and boundary conditions of the free trade zone construction on total factor productivity. This article divides enterprises into state-owned enterprises and non-state-owned enterprises according to the internal nature of the enterprise. This part explores from the 
perspective of the nature of the enterprise Impact of the construction of free trade zone on total factor productivity.

This section mainly studies whether there is a difference in the effectiveness of the promotion of total factor productivity between state-owned and non-state-owned enterprises under the pilot policy of the free trade zone. Table 4 is a report on its results. Both state-owned and non-state-owned enterprises in the free trade zone can promote total factor productivity. Increase, and the coefficient of non-state-owned enterprises is larger than that of state-owned enterprises, which indicates that non-state-owned enterprises are more able to improve the total factor productivity of enterprises in the construction of free trade zones. The table also found that the asset-liability ratio of state-owned enterprises has a significant impact on the improvement of total factor productivity. However, the asset-liability ratio of non-state-owned enterprises has little effect on the improvement of total factor productivity.

Table 4. The impact of different types of enterprises on total factor productivity

\begin{tabular}{|c|c|c|c|c|}
\hline \multirow[t]{2}{*}{1} & \multicolumn{2}{|c|}{ OLS } & \multicolumn{2}{|c|}{ FE } \\
\hline & (1) State-owned & (2) Non-state & (3) State-owned & (4) Non-state-owned \\
\hline \multirow[t]{2}{*}{$T \times G$} & $0.215 * * *$ & $0.221 * * *$ & $0.203 * * *$ & $0.223^{* * *}$ \\
\hline & $(0.042)$ & $(0.045)$ & $(0.042)$ & $(0.044))$ \\
\hline \multirow[t]{2}{*}{ age } & $0.018 * * *$ & $0.016 * * *$ & $0.016 * * *$ & $0.016^{* * *}$ \\
\hline & $(0.002)$ & $(0.002)$ & $(0.002)$ & $(0.002)$ \\
\hline \multirow[t]{2}{*}{$\ln L$} & $0.458 * * *$ & $0.479 * * *$ & $0.465 * * *$ & $0.477 * * *$ \\
\hline & $(0.011)$ & $(0.011)$ & $(0.011)$ & $(0.011)$ \\
\hline \multirow[t]{2}{*}{$n p m$} & 0.002 & $0.042 * *$ & 0.007 & $0.045^{* *}$ \\
\hline & $(0.016)$ & $(0.018)$ & $(0.016)$ & $(0.018)$ \\
\hline \multirow[t]{2}{*}{ roa } & $2.430 * * *$ & $0.700 * * *$ & $2.386^{* * * *}$ & $0.719 * * *$ \\
\hline & $(0.168)$ & $(0.0750$ & $(0.165)$ & $(0.074)$ \\
\hline \multirow[t]{2}{*}{$t d r$} & $0.576^{* * *}$ & 0.035 & $0.457 * * *$ & $0.047^{*}$ \\
\hline & $(0.075)$ & $(0.025)$ & $(0.074)$ & $(0.024)$ \\
\hline \multirow{2}{*}{ liquidityratio } & $0.068 * * *$ & $0.008 * *$ & $0.063 * * *$ & $0.008 * *$ \\
\hline & $(0.013)$ & $(0.003))$ & $(0.014)$ & $(0.003)$ \\
\hline Cons__ & 5.470 & 5.706 & 5.423 & 5.748 \\
\hline Within $-R^{2}$ & 0.403 & 0.389 & 0.381 & 0.391 \\
\hline Observations & 4035 & 3555 & 4035 & 3555 \\
\hline
\end{tabular}

Note: The parentheses in the parentheses are firm standard errors at the enterprise level, and $*^{* *}, * *$, and $*$ are significant at the levels of $1 \%, 5 \%$, and $10 \%$, respectively.

Based on the above heterogeneity analysis, we explore the reasons that.(1) The construction of the free trade zone promotes the improvement of total factor productivity through innovation-driven effects. Non-state-owned enterprises are more motivated to seek development in order to survive, and to employ advanced technology and technology. Talents with high management skills; while state-owned enterprises are generally co-invested by the central government or the central or local government. Compared with non-state-owned enterprises, state-owned enterprises pay more attention to fairness, resulting in lower efficiency than non-state-owned enterprises.(2) The construction of a free trade zone can affect total factor productivity through the effect of resource allocation. Non-state-owned enterprises have greater autonomy in adjusting resource allocation, and production factors can flow more quickly and freely, or even change their business scope. State-owned enterprises change resources Allocation, especially the streamlining of the labor force, is subject to more constraints, which are not conducive to the improvement of resource allocation by state-owned enterprises.

In summary, state-owned enterprises have relatively few constraints and higher efficiency in advancing innovation and resource allocation, leading to non-state-owned enterprises in the construction of free trade zones to have a stronger role in explaining total factor productivity. 


\section{Conclusions and Policy Implications}

(I) Research conclusions

After the 2008 financial crisis, China has gradually entered a new normal of economic growth. In order to achieve high-quality economic development, China has proposed policies and guidelines such as structural reforms on the supply side and further opening up of each other. The construction of the free trade zone is to further expand Opening up, improving the competitiveness of Chinese companies, and total factor productivity is an important indicator for measuring the development status of enterprises. This article is based on the panel data of China a-share listed companies from 2004 to 2018. An empirical analysis was conducted to promote the total factor productivity of enterprises. The results are as follows:

(1) The effect of the multi-period did policy evaluation shows that after controlling the fixed effect of the time or the fixed effect of the industry, the coefficient of influence of the free trade zone construction on total factor productivity is significantly positive, indicating that the establishment of the free trade zone has significantly improved the total factor productivity of enterprises.

(2) The construction of the free trade zone can promote the development of total factor productivity through innovation-driven effects and resource allocation effects. This article uses the patent data obtained by the company as an agent for innovation, and innovation-driven has a significant intermediary effect. Promote the level of innovation and thereby increase the total factor productivity of enterprises.

(3) This article also analyzes the heterogeneity of enterprises and divides them into state-owned enterprises and non-state-owned enterprises. It is believed that during the construction process of the free trade zone, non-state-owned enterprises play a greater role in promoting total factor productivity. .

\section{( II ) Policy inspiration}

The research in this paper believes that promoting trade liberalization and building a high-quality free trade zone are important to improve the total factor productivity of enterprises. According to the conclusions, this article proposes the following three suggestions for the construction of a free trade zone.

(1) Technological innovation plays an important role in the construction of the free trade zone and the improvement of total factor productivity. The construction of the free trade zone requires the establishment of a good business environment and the improvement of the free trade zone's ability to attract technology and talents. First, we must make full use of the free trade zone. The various preferential policies of the free trade zone stimulate the innovative vitality of the main body of the enterprise, so that the company fully participates in international market competition, research and development and learning of advanced technology and management capabilities; secondly, the free trade zone should actively introduce foreign companies with high and new technology to promote foreign business Technology investment, relying on technology spillover effects to promote the overall technical level of local enterprises; third, increase cooperation in free trade zones with universities, research institutes, and technological innovation platforms to promote the transformation and application of scientific research results.

(2) The allocation of resources plays a regulatory effect between the free trade zone and total factor productivity. To play the role of the free trade zone on total factor productivity, it is necessary to improve the efficiency of resource allocation. First, the free trade zone must give full play to the role of the market itself To use invisible revenue to improve the efficiency of enterprise resource allocation, it is also necessary to play the role of government intervention and use a negative list policy to prevent foreign-invested enterprises that are not conducive to the long-term and high-quality development of the free trade zone economy. Second, the free trade zone should establish a good The business environment, using the advantages of foreign capital to enjoy national treatment, promoting fair competition among enterprises, building a sound modern industrial system, optimizing resource allocation, and promoting total factor productivity.

(3) Pay attention to the role played by the heterogeneity of enterprises in the free trade zone in promoting total factor productivity. First, according to the nature of enterprises, state-owned enterprises must give play to their own financing advantages, attract global high-level talents, and focus on technological innovation; Non-state-owned enterprises give play to their efficiency advantages, according to their own advantages, to avoid weaknesses, and to find the path that is most suitable for the development of enterprises. Second, the industries and regions of the companies in the free trade zone are heterogeneous. The industry is looking for a way to increase productivity, but can't walk in Handan. According to the actual situation, technological innovation and resource allocation should be carried out in accordance with the actual conditions and in accordance with local conditions in order to improve the total factor productivity of enterprises and enable them to develop with high quality and health. 


\section{References}

Bi, Y. J., Tang, H. Y., \& Yin, D. S. (2014). Restrictive factors and countermeasures faced by the transition of Shanghai Free Trade Zone [J]. Economic Survey, 8, 8-12.

Chen, A. Z., \& Liu, Z. B. (2014). Free Trade Zone: "Second Season" of China's Open Economy [J]. Academic Monthly, 1, 20-28.

Chen, Q., \& Liu. W. (2014). Analysis of the Motives and Economic Effects of Establishing China (Shanghai) Pilot Free Trade Zone [J]. Science Development, 2, 43-50.

Chen, S. H., Tao, L. Y., \& Huang, J. (2014). Research on the Development of Service Trade in the Background of Shanghai Free Trade Zone [M]. Fudan University Press, First Edition, May 2014.

Ding, Y. B., Fu, Y. J., \& Cao, Y. (2014). Financial Development, Technological Innovation, and Industrial Structure Optimization: An Empirical Analysis Based on Middle-income Countries [J]. Industrial Economic Review, 1, 82-99.

Expert Group of Shanghai University of International Business and Economics. China (Shanghai) Pilot Free Trade Zone and International Economic Cooperation [M]. Shanghai University of Finance and Economics Press, December 2013 First Edition.

Hu, B. W. (2014). Financing Constraints of Chinese Manufacturing Listed Companies [D]. Master's Thesis of Nanjing University. 2014.

Levinsohn, J. M., \& Petrin, A. (2003). Estimating Production Functions Using Inputs to Control for Unobservables [J]. Review of Economic studies, 70(2), 317-341. https://doi.org/10.1111/1467-937X.00246

Liu, B. X., \& Lu, C. (2018). Differential Analysis of the Impact of Free Trade Area on Regional Economy: A Comparative Study Based on Synthetic Control Method [J]. International Trade Issues, 3, 51-66.

Liu, B. X., \& Wang, Y. (2018). Study on the Effect of Free Trade Zone on Regional Innovation Capability-Evidence from the Quasi-Experiment of Shanghai Free Trade Pilot Zone [J]. Economic and Management Research, 9, 65-74.

Liu, Q. Y., \& Liu, Z. L. (2017). Research on the role of information technology in promoting the upgrading of the publishing industry [J]. China Publishing, 21, 63-65.

Lu, X. D., \& Lian, Y. J. (2012). Total Factor Productivity Estimates of Chinese Industrial Enterprises: 1999-2007 [J]. Economics (Quarterly), 2, 541-558.

Massimo, D. G., Adrianna, D. L., \& Petraglia, C. (2018). Measuring Productivity [J].Working paper CRENoS 2008.

Sheng, B. (2017). Evaluation and Prospect of China's Pilot Free Trade Zone [J]. International Trade, 6, 7-13.

Tan, N., Zhou, X. B., \& Lin, J. H. (2015). Research on the Economic Growth Effect of Shanghai Free Trade Zone: A Counterfactual Analysis Method Based on Panel Data [J]. International Trade Issues, 10, 14-24.

Thorsten, B., Ross, L., \& Alexey, L. (2010). Big Bad Banks? The winners and Losers from Bank Deregulation in the United States [J]. The Journal of Finance, 65(5), 1637-1667. https://doi.org/10.1111/j.1540-6261.2010.01589.x

Wang, L. H., \& Liu, Z. H. (2017). Research on the Impact of Shanghai Free Trade Zone on Regional Economy [J]. International Trade Issues, 2, 3-15.

Xiang, H. J., \& He, K. (2016). Impact of Free Trade Zone and Capital Flow: A Natural Experimental Study with Shanghai as an Example [J]. International Trade Issues, 8, 3-15.

Xie, Q. L., Roski, \& Zhang, Y. F. (2018). Growth and Convergence of China's Industrial Productivity [J]. Economics (Quarterly), 3, 809-826.

Yang, X. D. (2014). Preliminary Study on the Relationship between Economic and Political Effects in China (Shanghai) Pilot Free Trade Zone [J]. Journal of Shanghai University of Finance and Economics, 6, 97-104.

Zhang, J., Li, Y., \& Liu, Z. B. (2009). Does Export Promote the Productivity of Chinese Enterprises? Evidence from Chinese Local Manufacturing Enterprises [J]. Management World, 12, 11-26.

Zhang, Y. W. (2014). Experiment in Free Trade Zone and Construction of Open Economic System [J]. Academic Monthly, 4, 11-19.

Zhuo, C. F., \& Deng, F. (2018). Interregional flow of innovation factors and industrial structure upgrade [j]. 
Exploration of Economic Issues, 5, 70-79.

\section{Copyrights}

Copyright for this article is retained by the author(s), with first publication rights granted to the journal.

This is an open-access article distributed under the terms and conditions of the Creative Commons Attribution license (http://creativecommons.org/licenses/by/4.0/). 